\title{
PENGARUH PENAYANGAN FILM ANIMASI 3D TRAILER TERHADAP RECALL AUDIENCE DI BLITZ HARBOUR BAY MALL BATAM
}

\author{
Weni Lestari Putri \\ Program Studi Teknik Informatika Universitas Putera Batam
}

\begin{abstract}
This research is done in Cinema Blitz Harbour Bay Mall Batam. And under study is views 3D Animation Trailer for recall audience. And can see the extent of its influence. The model of this research is quantitative. Judging from the number of visitors and visitor attraction to the views of $3 D$ animation trailer how many visitors are present. How it felt itself. From the definition 3D animation Trailer Includes synopsis of the film fullnya. And of itself adalh Audience Recall appeal the significant effect in terms of whether or not these two variables. The researchers also wanted to examine both the variable and its object in Blitz Harbour bay mall Batam. Through dedication and research institutes community (SBRC) University lecturer Son Batam this I could research and develop the knowledge I ampu for this.
\end{abstract}

Keywords: 3D animation trailer, Recall Audience

\section{PENDAHULUAN}

Recall membutuhkan daya tarik agar pesan yang disampaikan kepada konsumen. Contoh iklan seperti jinggle dan trailer untuk mempromosikan filmnya. Film trailer sendiri itu termasuk iklan yang memberikan sinopsis film sendiri agar para konsumen tertarik dan penasaran untuk menonton. Ada banyak cara produksi film membuat film yang sangat beda dari yang biasanya. Misalnya saja film animasi 3D, yang sekarang menjadi populer di dunia perfilman apalagi animasi yang sudah mendunia contohnya Doraemon. Dari dulu film Doraemon sangat diminati anak-anak dari tahun ke tahun. Maka anak anak dan saat ini menjadi dewasa masih suka dengan Doraemon. Saat ini juga film Doraemon yang berbasis 3D yang berjudul "Stand By Me Doraemon" akan diluncurkan di indonesia di megablitz desember ini. Antusias masyarakat sangat besar dan sangat ditunggu-tunggu oleh para penonton. Dari film Trailer kita sudah bisa membayangkan bagaimana film tersebut. Masih banyak lagi film animasi 3D yang sudah ditonton. Tetapi sebelum itu pastinya kita lihat trailer barulah kita tahu bagaimana 
gambarannya. Maka dari itu bisnis trailer banyak membuat peminat tontonan animasi 3D pada penasaran, dan ingin secepatnya menonton.

Perfilman animasi tiga dimensi sangat diminati masyarakat khususnya di Batam, banyaknya bioskop yang ada di tempat-tempat perbelanjaan membuat masyarakat beramairamai ke tempat itu. Antusias masyarakat sangat banyak, bukan hanya kalangan anak-anak tetapi kalangan orang dewasa. Karena tiga dimensi juga membuat visual menjadi nyata. Bukan karena animasinya atau artnya, tetapi dunia film kartun membuat kita dari dunia nyata masuk ke dalam dunia animasi. Tiga dimensi sendiri masuk kedalam virtual reality karena cakupannya hampir ke dunia nyata. Tetapi bila kita tidak memakai kaca mata 3 dimensi maka tidak pengaruh film animasi yang kita tonton terlihat biasa saja.

Dari kedua pokok itu, maka digabungkan dari film animasi 3 dimensi dan animo masyarakat terutama di Batam, karena untuk kawasan Batam sendiri kota industri yang banyak masyarakatnya bekerja sebagaimana tanggung jawab karyawan, belum lagi jam bekerja mereka. Waktu senggang film animasi 3 dimensi inilah sebagai penghibur hati mereka, dikala kesibukan mereka sehari-hari dalam bekerja. Menjadi suatu minat mereka untuk menonton dan menghibur hati. Banyak pula aneka film animasi 3 dimensi yang ditawarkan perusahaan perfilman dunia di Indonesia, menjadi pilihan masyarakat akan adanya movie animasi 3D. Maka dari itu peniliti mengangkat judul "Pengaruh Penayangan Film Animasi 3D Trailer terhadap Recall Audience di Blitz Harbour Bay mall Batam"

\section{KAJIAN PUSTAKA DAN PENGEMBANGAN HIPOTESIS}

\section{Film Animasi 3D Trailer}

Di jepang, Seperti halnya di Eropa, perkembangan animasi tidak terlepas dari pesatnya perkembangan komik. Pemutaran serial animasi TV “Tetsuwan Atom (Astro Boy)" merupakan film animasi pertama yang sukses di jepang. Film yang diangkat dari komik populer karya Osamu Tezuka dianggap sebagai pelopor industri animasi Jepang. Kisah kepahlawanan dan petualangan robot angkasa mendominasi perkembangan animasi pada tahun 1970 - an dan 1980 - an. Animasi jepang tidak terlepas dari maraknya dunia komik jepang (dikenal dengan sebutan manga). Sampai pada dekade ini (tahun 2000 - an), telah muncul ratusan film - film anime yang sangat populer di seluruh dunia, seperti anime "Doraemon", "Dragon Ball", "Sailormoon", "Detektif Conan", "Shinchan", "Samurai X”, "Naruto", "Slum Dunk", "Digimon" dan Sebagainya. Tidak dapat dipungkiri jika animasi animasi jepang (yang dikenal juga dengan sebutan anime) semakin mengokohkan posisinya 
sebagai animasi paling sukses di dunia, bahkan sebagai pemberi devisa terbesar nomor dua bagi negara jepang.

Secara umum, animasi dapat dibagi ke dalam tiga katagori yaitu traditional animation (2D animation), stop motion animation, dan computer graphics (3D animation).

\section{1. traditional animation ( $2 D$ animation)}

Animasi Tradisional (traditional animation) adalah katagori animasi yang sudah berumur sangat tua. Disebut tradisional karena teknik/model animasi inilah yang digunakan untuk pengembangan awal animasi di media layar kaca (TV) dan layar perak (Bioskop). Traditional animation sering disebut dengan cell animation sering disebut dengan cell animation karena teknik pengerjaannya dilakukan pada media kertas celluloid transparent adalah kertas yang tembus pandang sehingga animator dengan mudah membuat gambar yang saling berurutan satu sama lain dan dapat menciptakan animasi yang tampak halus dan mulus pergerakannya.

2. stop motion animation

Stop motion animation adalah animasi yang menggunakan media perekam, misalnya kamera, untuk menangkap pergerakan objek yang digerakkan sedikit demi sedikit. Dalam jenis animasi ini, objek akan diatur untuk memperlihatkan pose tertentu dan kamera akan merekam pose objek tersebut. Proses gerak objek dan rekam pose akan terjadi berulang kali. Hasilnya, ketika kamera memutar pose - pose objek secara cepat, terciptalah ilusi pergerakan animasi. Animasi ini sering disebut juga dengan claymation karena, dalam perkembangannya, jenis animasi ini umumnya menggunakan media atau bahan berupa tanah liat (clay) sebagai objek animasinya. Clay tersebut digunakan untuk membuat objek animasi berupa boneka, patung, dan sebagainya. Clay dipilih karena bahan ini bersifat elastis (mudah dibentuk) dan mudah untuk digerakkan. Namun, animasi jenis ini tidak hanya terbatas pada objek berbahan tanah liat saja, kertas, kayu, dan bahan lain pun dapat digunakan dalam animasi jenis ini.

3. computer graphics (3D animation)

computer graphic animation adalah jenis animasi yang keseluruhan prosesnya dikerjakan dengan media komputer. Animasi ini dapat berupa animasi 2 dimensi (2D) dan 3 dimensi (3D). Namun, dalam perkembangannya, computer graphic animation ini telah berevolusi dengan sangat cepat melalui pendekatan 3D yang sangat revolusi dengan sangat cepat melalui pendekatan 3D yang sangat revolusioner dan bahkan mampu mendekati bentuk objek aslinya (hyperreality) sehingga pada akhirnya, animasi jenis ini menjadi identik dengan animasi 3D (3D animation). Dengan bantuan komputer, 
maka seluruh pengerjaan animasi, mulai dari tahap permodelan hingga hasil akhir (rendering), tidak lagi dikerjakan dengan sketsa tangan manual (konvensional) sehingga cepat. Computer graphic animation saat ini dikenal juga dengan istilah Computer Generated imagery (CGI). Aditya ( 2009: 6 - 13 )

Animasi berasal dari bahasa latin, yakni anima yang artinya jiwa, hidup, nyawa dan semangat. Dalam bahasa inggris, animasi diambil dari kata animate (menjiwai atau menghidupkan dan animation (semangat atau gelora). (Aditya, 2009:2).

Animasi 3D adalah animasi yang berwujud 3 dimensi. Meskipun bukan dalam wujud 3D yang sebenarnya, yaitu bukan sebuah objek 3D yang dapat disentuh dan merasakan wujud fisiknya, namun dalam wujud 3D dalam layar kaca 2D (media layar TV, Bioskop, komputer, proyektor, dan media sejenisnya). Tidak seperti animasi 2D yang hanya memiliki dimensi panjang (X) dan lebar (Y), animasi 3D selain memiliki kedua dimensi tersebut juga memiliki dimensi kedalaman (Z). Animasi 2D bersifat datar (flat), sedangkan animasi 3D memiliki kedalaman (volume) bentuk. Animasi 3D dapat didefinisikan sebagai animasi yang dapat dilihat dari berbagai sudut pandang (Point Of view). Tahapan animasi 3D secara keseluruhan dikerjakan dengan media komputer, mulai tahap modelling, texturing, lighting, sampai Rendering. Jenis keunggulan utama dari animasi 3D adalah visualisasi objek yang tampak lebih nyata dan mendekati bentuk aslinya. Keunggulan lain adalah kemampuannya untuk membuat dan mewujudkan visualisasi adegan yang sulit, yang tak mungkin atau bahkan yang tampak mustahil. Jenis animasi 3D dapat dibagi dalam tiga katagori utama yaitu animasi 3D penuh (full), animasi 3D dan 2D, serta animasi 3D dan live Shoot.

1. Animasi 3D penuh (Full)

Jenis ini menggunakan animasi objek 3D secara penuh (full). Seluruh tampilan 3D maupun proses pembuatannya menggunakan teknik animasi 3D maupun proses pembuatannya menggunakan teknik animasi 3D.

\section{Animasi 3D dan 2D}

Jenis animasi ini merupakan penggabungan antara animasi 3D dengan animasi 2D. Biasanya tokoh dan karakter animasinya berupa animasi 2D dengan latar belakang (backround) maupun peralatan, serta propertinya menggunakan animasi 3D. Ini dilakukan untuk mempermudah proses pembuatan karakter 3D memiliki tingkat kerumitan yang lebih tinggi dan proses yang lebih mendetail dibandingkan dengan karakter 2D. 


\section{Animasi 3D dan Live Shoot}

Jenis Animasi ini menggabungkan antara animasi 3D dengan Syuting langsung (live shoot). Animasi jenis ini banyak diterapkan pada film - film Hollywood, misalnya film "Titanic", "Jurrasic Park", "Star Wars", "Stuart Little", "Lord of The Ring". Teknik ini digunakan untuk membuat dengan adegan yang rumit, yang tidak mungkin, dan bahkan mustahil dilakukan dalam kondisi yang sebenarnya (nyata). Dengan teknik ini, biaya produksi juga dapat dihemat dan proses produksi juga tidak memakan waktu yang lama. Dengan demikian, para sineas maupun pencipta film dapat berkreasi tinggi bahkan seliar mungkin untuk membuat film - film yang berkualitas, menarik, dan menjadi box office dunia. Aditya (2009:14 - 18$)$.

\section{Indikator penayangan film animasi 3D trailer adalah :}

1. Editing Animation and Voice

Proses pengeditan pada hasil animasi yang telah dibuat dan juga pengeditan pada suara. Dalam proses ini, klip animasi atau suara yang tidak diperlukan dibuang.

\section{Compositing and Visual Effect}

Compositting pada elemen - elemen animasi serta pembuatan visual effect yang dibutuhkan, misalnya pembuatan judul, atau bumper/flying logo atau penambahan efek efek visual yang memperindah tampilan animasi, seperti pemberian efek cahaya, sinar, ledakan, dan lain - lain.

\section{Adding Sound and audio/Folley}

Proses pemberian audio sebagai pendukung visual animasi. Proses ini biasanya dilakukan di dalam sebuah ruangan dengan berbagai peralatan yang menghasilkan bunyi bunyian sesuai dengan adegan yang dibutuhkan dalam animasi.

\section{Preview and final}

Tahap penyatuan keseluruhan animasi, audio, dan compositting yang telah dibuat.

\section{Burn to Tape}

Proses pemindahan hasil animasi ke media pita untuk di putar di bioskop atau stasiun TV. Media penyimpanan lain juga banyak digunakan saat ini adalah media penyimpanan digital, yaitu CD atau DVD. (Aditya, 2009 : 36).

\section{Recall Audience}

Menurut wells, et al (2006 : 116), recall audience adalah kemampuan daya ingat seorang audience dalam mengingat kata demi kata dari iklan yang dipasang sehingga audience mampu mengingat penanyangan iklan produk yang diiklankan sebelumnya dan mengutarakan kembali apapun yang bisa diingat. 
Periklanan merupakan penggunaan media bayaran oleh seorang penjual untuk mengkomunikasikan informasi persuasif tentang produk, jasa ataupun organisasi dan merupakan alat promosi yang kuat. Iklan mempunyai berbagai macam bentuk (nasional, regional, lokal; konsumen, industri, eceran; produk, merek, lembaga; dan sebagainya) yang dirancang untuk mencapai berbagai macam tujuan (penjualan seketika, pengenalan merek, preferensi dan sebagainya).

Pengambilan keputusan periklanan merupakan proses yang terdiri dari penetapan tujuan, keputusan tentang anggaran, keputusan pesan, penetapan media dan evaluasi mengenai kampanye. Pemasangan iklan harus menyusun sasaran yang jelas sesuai dengan tujuan iklan. Yakni untuk memberi informasi, persuasi, mengingatkan para pembeli, menambah nilai atau membantu usaha promosi lainnya (Suyanto, $2007: 143$ )

\section{Indikator dari Recall Audience}

Untuk menentukan daya tarik mana kemungkinan tingkat keberhasilannya paling tinggi terhadap target sasaran, harus dilakukan analisis dan riset pasar. Daya tarik pesan dapat menggunakan selebritis, humor, kesalahan, perbandingan dll. (Suyanto, 2003 : 158$165)$.

1. Daya Tarik Selebriti

Produk dapat menonjol dalam periklanan salah satunya menggunakan daya tarik figure masyarakat. Figur masyarakat tersebut dapat berupa seorang tokoh, bintang TV, aktor, aktris, ilmuwan, atlet dan sebagainya. Selebritis adalah pribadi atau tokoh yang dikenal masyarakat untuk mendukung suatu produk.

\section{Daya Tarik Humor}

Pengiklan juga menggunakan humor untuk mencapai sasaran komunikasi yang bervariasi untuk memicu perhatian, memandu konsumen secara menyeluruh terhadap tuntutan produk, mempengaruhi sikap menyempurnakan kemampuan recall dari tuntutan pengiklan, dan pada akhirnya menciptakan tindakan konsumen untuk membeli produk.

3. Daya Tarik Kesalahan

Daya tarik kesalahan dapat berjalan baik karena memotivasi individu dewasa secara emosi mengambil alih tanggung jawab tindakan kedepan mengurangi kesalahan. Pengiklan menggunakan daya tarik kesalahan dan berusaha membujuk calon konsumen dengan menerapkan perasaan bersalah yang dapat diganti dengan menggunakan produk diiklankan atau menunjukkan kesalahan agar konsumen tidak mengulanginya.

\section{Daya Tarik Komparatif}


Praktek dalam periklanan, komparatif langsung atau tidak langsung suatu produk dengan produk pesaing, yang mempromosikan bahwa produk tersebut superior dibandingkan produk pesaing dalam pembelian disebut iklan komperatif.

5. Daya Tarik Rasional

Daya Tarik rasional berfokus pada praktik, fungsi atau kebutuhan konsumen secara optimal terhadap suatu produk, yang memberikan tekanan pada manfaat atau alasan untuk mempunyai atau menggunakan suatu merek.

6. Daya Tarik Emosional

Daya tarik emosional berhubungan dengan psikologis konsumen untuk membeli suatu produk. Banyak konsumen untuk membeli suatu produk karena emosional dan perasaan terhadap merek dapat menjadi lebih penting daripada pengetahuan terhadap atribut dan pernak-pernik produk tersebut.

\section{KERANGKA BERFIKIR DAN HIPOTESIS}

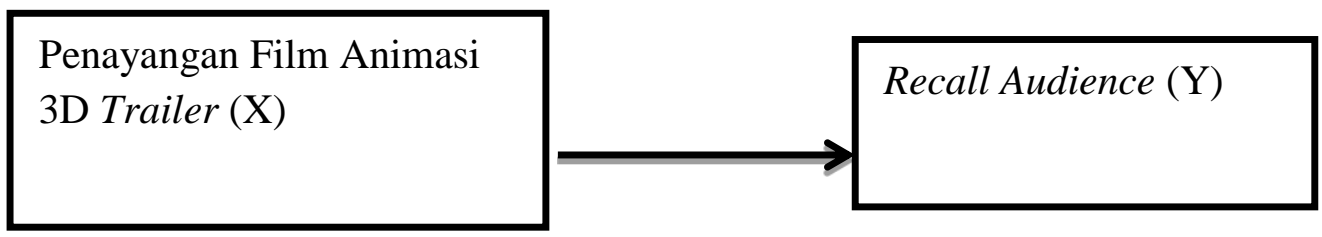

Gambar 2. Kerangka Berfikir

\section{HIPOTESIS :}

1. Penayangan film animasi 3D trailer menarik pengunjung.

2. Recall audience meningkat pada bioskop Blitz Barbour bay batam.

3. Penayangan Film animasi 3D trailer berpengaruh signifikan terhadap Recall audience di bioskop Harbour Bay Mall Batam.

\section{METODE PENELITIAN}

Jenis penelitian ini yang digunakan penulis berdasarkan tingkat eksplanasi, adalah jenis penelitian deskriptif dan asosisatif. "Penelitian deskriptif adalah suatu penelitian yang berkenaan dengan pertanyaan terhadap keberadaan variabel mandiri, baik hanya pada satu variabel atau lebih (variabel yang berdiri sendiri). Sedangkan penelitian assosiatif adalah penelitian yang bersifat menanyakan hubungan antara dua variabel atau lebih."(Sugiyono, 2012: 35-36).

Pengunaan jenis penelitian deskriptif untuk menjelaskan bagaimana pengaruh penayangan animasi 3D trailer dan recall audience pada blitz Harbour Bay Mall Batam. 
Sedangkan, jenis penelitian asosiatif digunakan untuk mengetahui hubungan antar dua variabel atau lebih. Dalam hal ini, penulis mengunakan hubungan kausal untuk mengetahui hubungan sebab akibat variabel yang terkait. Menurut Sugiyono (2012: 37), "Hubungan kausal adalah hubungan yang bersifat sebab akibat. Jadi disini ada variabel independen (variabel yang mempengaruhi) dan dependen (dipengaruhi)".

\section{HASIL DAN PEMBAHASAN}

\section{HASIL PENELITIAN}

\section{Profil Responden}

Untuk memperoleh data pengujian ini, penulis membagikan kuesioner pada 150 responden. Jumlah sampel kuesioner tersebut dihasilkan berdasarkan kuota yang di inginkan penulis. kuesioner tersebut dibagikan kepada pengunjung pada akhir desember 2014 - awal januari. Berikut ini adalah pengelompokan profil responden yang dibagi berdasarkan umur, jenis kelamin dan pendidikan.

\section{Umur}

Dapat diketahui bahwa jumlah umur responden berusia 15 - 30 tahun adalah 134 orang dengan persentasi 89,3\%, yang berumur 31-45 tahun adalah 14 orang dengan persentasi 9,3\%, dan yang berumur diatas 46 tahun adalah 20 orang dengan persentasi 9,3\%. Hal ini menunjukkan bahwa umur 15 -30 tahun lebih besar dalam Daya tarik pada film animasi 3D.

\section{Jenis Kelamin}

dapat diketahui bahwa yang jenis kelaminnya laki - laki adalah 81 orang dengan persentasi $45 \%$, dan yang jenis kelaminnya perempuan adalah 69 orang dengan persentasi 46\%. Hal ini menunjukkan jenis kelamin laiki - laki lebih besar dalam Daya tarik pada film animasi 3D.

\section{Pendidikan}

Dapat diketahui bahwa yang Pendidikan tamatan SD adalah 7 orang dengan persentasi 4,7 \%, yang pendidikan tamatan SMP adalah 5 orang dengan persentasi 3,3\%, yang tamatannya SMA/SMK/MA adalah 127 orang dan persentasi 84,7 \% dan yang tamatan S1/S2/S3 adalah 11 orang dengan persentasi 7,3\%. Hal ini menunjukkan Pendidikan tamatan SMA/SMK/MA lebih besar dalam Daya tarik pada film animasi 3D.

\section{ANALISIS DESKRIPTIF}

Berdasarkan operasional variabel yang telah dijelaskan sebelumnya, adapun indikator-indikator setiap variabel dapat dilihat pada tabel 4.4 dibawah ini:

\section{Penayangan Film Animasi $3 D$ Trailer}

Pada variabel X (Penayangan Film Animasi 3D Trailer) terdapat 5 indikator mempunyai 5 item pertanyaan kuisioner dengan beberapa pertanyaan antara lain sebagai berikut: 
Tabel 1. Penayangan Film Animasi 3D Trailer $(\mathrm{X})$

\begin{tabular}{|c|c|c|}
\hline Item & SKOR & KONSTRIBUSI \\
\hline $\begin{array}{l}\text { Penayangan Film Animasi 3D Trailer memiliki } \\
\text { animasi yang bagus dan Suara yang Jernih seperti } \\
\text { nyata. }\end{array}$ & 486 & $12.96 \%$ \\
\hline $\begin{array}{l}\text { Penayangan Film Animasi 3D Trailer memiliki } \\
\text { kualitas efek tampilan menarik agar kalian ingin } \\
\text { menonton. }\end{array}$ & 524 & $13.97 \%$ \\
\hline $\begin{array}{l}\text { Penayangan Film Animasi 3D Trailer memiliki } \\
\text { bunyian sebagai kejutan seperti bunyi banting benda } \\
\text { jatuh. Seperti bunyi yang nyata. }\end{array}$ & 503 & $13.4 \%$ \\
\hline $\begin{array}{l}\text { Tampilan Penayangan Film Animasi 3D Trailer } \\
\text { Sangat menarik untuk di tonton. }\end{array}$ & 552 & $14.72 \%$ \\
\hline $\begin{array}{l}\text { Penayangan Film Animasi 3D Trailer, sangat menarik } \\
\text { jika menonton di bioskop untuk Film Langsung. } \\
\text { Bukan hanya sebagai trailer tetapi langsung di theater } \\
\text { seperti menonton di Blitz Harbour Bay Mall }\end{array}$ & 528 & $14.08 \%$ \\
\hline Total Skor Aktual & 2593 & $69.14 \%$ \\
\hline Total Skor Ideal & 3750 & \\
\hline Rata - Rata Skor & 518.6 & \\
\hline
\end{tabular}

Rata-rata dari 5 indikator dan 5 pertanyaan pada tabel 1, Variabel (X) adalah 2593. Rata-Rata skor ini berada pada rentang skala (513- 633). Dengan demikian Ho ditolak (Penayangan film animasi 3D trailer tidak menarik pengunjung.) dan $\mathrm{H} 1$ di terima (Penayangan film animasi 3D trailer menarik pengunjung).

\section{Recall Audience}

Pada variabel Y (Recall audience) terdapat 6 indikator mempunyai 3 item pertanyaan kuisioner dengan beberapa pertanyaan antara lain sebagai berikut:

Tabel 2. Recall Audience (Y)

\begin{tabular}{|l|l|l|}
\hline Item & SKOR & DISTRIBUSI \\
\hline $\begin{array}{l}\text { Daya Tarik Tokoh Utama menentukan Penonton ingin } \\
\text { menonton di Blitz Harbour Bay Mall. }\end{array}$ & 476 & $21.15 \%$ \\
\hline $\begin{array}{l}\text { Film yang mempunyai Kesan Humor memiliki daya tarik } \\
\text { Penonton agar ingin menonton }\end{array}$ & 529 & $23.51 \%$ \\
\hline $\begin{array}{l}\text { Film animasi 3D memiliki daya tarik Rasional yang bersifat } \\
\text { memberikan pesan moral kepada Penonton. }\end{array}$ & 452 & $20.08 \%$ \\
\hline Total Skor Aktual & 1457 & $64.75 \%$ \\
\hline Total Skor Ideal & 2250 & \\
\hline Rata - Rata Skor & 4371 & \\
\hline
\end{tabular}

Rata-rata dari 6 indikator dan 3 pertanyaan pada tabel 2, Variabel (X) adalah 2593. Rata-Rata skor ini berada pada rentang skala (392 - 512). Dengan demikian Ho ditolak (Recall audience menurun pada bioskop blitz harbour bay mall Batam.) dan $\mathrm{H} 1$ di terima (Recall audience cukup meningkat pada bioskop blitz harbour bay mall Batam) 


\section{Hasil Uji Validitas}

\section{Penayangan Film Animasi 3D Trailer}

Item-Total Statistics

Tabel 3. Hasil Uji validitas X

\begin{tabular}{|l|r|r|l|l|l|}
\hline & $\begin{array}{l}\text { Scale Mean if } \\
\text { Item Deleted }\end{array}$ & $\begin{array}{l}\text { Scale Variance } \\
\text { if Item } \\
\text { Deleted }\end{array}$ & $\begin{array}{l}\text { Corrected } \\
\text { Item-Total } \\
\text { Correlation }\end{array}$ & $\begin{array}{l}\text { Squared } \\
\text { Multiple } \\
\text { Correlation }\end{array}$ & $\begin{array}{l}\text { Cronbach's } \\
\text { Alpha if Item } \\
\text { Deleted }\end{array}$ \\
\hline X1 & 13.7267 & 9.327 & .608 & .449 & .794 \\
X2 & 13.4733 & 9.929 & .612 & .389 & .791 \\
X3 & 13.6133 & 10.158 & .572 & .439 & .802 \\
X4 & 13.6067 & 9.851 & .651 & .595 & .781 \\
X5 & 13.4467 & 9.766 & .657 & .598 & .778 \\
\hline
\end{tabular}

Sumber : Pengolahan data SPSS 19

Dari hasil uji validitas, maka diketahui untuk $r$ tabelnya adalah 0.1603. Dari hasil uji validitas pada variabel $\mathrm{X}$ terlihat bahwa semua item skor dari pertanyaan adalah Corrected Item-Total Correlation > $\mathrm{r}$ tabel, hal ini menjelaskan bahwa $\mathrm{r}$-hitung $>\mathrm{r}$-tabel yang berarti setiap instrumen dari item pertanyaan dinyatakan valid. Dengan demikian maka sebelas item pertanyaan dari variabel Penayangan Film Animasi 3D Trailer (X) dinyatakan valid dan dapat digunakan dalam pengujian berikutnya.

\section{Recall Audience}

Tabel 4. Hasil Uji validitas $Y$

Item-Total Statistics

\begin{tabular}{|l|r|r|l|l|l|}
\hline & $\begin{array}{l}\text { Scale Mean if } \\
\text { Item Deleted }\end{array}$ & $\begin{array}{l}\text { Scale Variance } \\
\text { if Item } \\
\text { Deleted }\end{array}$ & $\begin{array}{l}\text { Corrected } \\
\text { Item-Total } \\
\text { Correlation }\end{array}$ & $\begin{array}{l}\text { Squared } \\
\text { Multiple } \\
\text { Correlation }\end{array}$ & $\begin{array}{l}\text { lronbach's } \\
\text { Alpha if Item } \\
\text { Deleted }\end{array}$ \\
\hline Y1 & 6.9000 & 3.151 & .632 & .402 & .728 \\
Y2 & 6.6867 & 3.559 & .617 & .384 & .743 \\
Y3 & 6.8400 & 3.209 & .667 & .445 & .688 \\
\hline
\end{tabular}

Sumber : pengolahan data SPSS 19

Dari hasil uji validitas, maka diketahui untuk $r$ tabelnya adalah 0.1603. Dari hasil uji validitas pada variabel $\mathrm{Y}$ terlihat bahwa semua item skor dari pertanyaan adalah Corrected Item-Total Correlation > $\mathrm{r}$ tabel, hal ini menjelaskan bahwa $\mathrm{r}$-hitung $>\mathrm{r}$-tabel yang berarti setiap instrumen dari item pertanyaan dinyatakan valid. Dengan demikian maka sebelas item pertanyaan dari variabel Recall Audience dinyatakan valid dan dapat digunakan dalam pengujian berikutnya. 


\section{Hasil Uji Realibilitas}

\section{Penayangan Film Animasi $3 D$ Trailer}

Tabel 5. Hasil Uji Reabilitas X

Reliability Statistics

\begin{tabular}{|l|l|l|}
\hline Cronbach's Alpha & $\begin{array}{l}\text { Cronbach's Alpha Based } \\
\text { on Standardized Items }\end{array}$ & N of Items \\
\hline 824 & .826 & 5 \\
\hline
\end{tabular}

Sumber : Pengolahan SPSS 19

Dari hasil pengolahan data dapat dilihat bahwa nilai crobanch's alpha untuk uji reliabilitas adalah 0,824 > 0,60 dengan demikian, dapat disimpulkan bahwa alat ukur dalam item pertanyaan (X) dapat dipercaya (reliable).

\section{Recall Audience}

Tabel 6. Hasil Uji Reabilitas Y

\section{Reliability Statistics}

\begin{tabular}{|l|l|l|}
\hline Cronbach's Alpha & $\begin{array}{l}\text { Cronbach's Alpha Based } \\
\text { on Standardized Items }\end{array}$ & N of Items \\
\hline 795 & .795 & 3 \\
\hline
\end{tabular}

Dari hasil pengolahan data dapat dilihat bahwa nilai crobanch's alpha untuk uji reliabilitas adalah 0,824 > 0,60 dengan demikian, dapat disimpulkan bahwa alat ukur dalam item pertanyaan (X) dapat dipercaya (reliable).

\section{HASIL UJI ASUMSI KLASIK}

\section{Hasil Uji Normalitas Data}

Sebelum ditentukannya, dilakukan uji normalitas data. Jika data distribusi normal, maka uji hipotesis menggunakan statistik parametis. Jika data tidak terdistribusi normal maka uji hipotesis menggunakan statistik non parametis. Uji normalitas data betujuan untuk menguji apakah dalam model regresi, memiliki distribusi normal. 


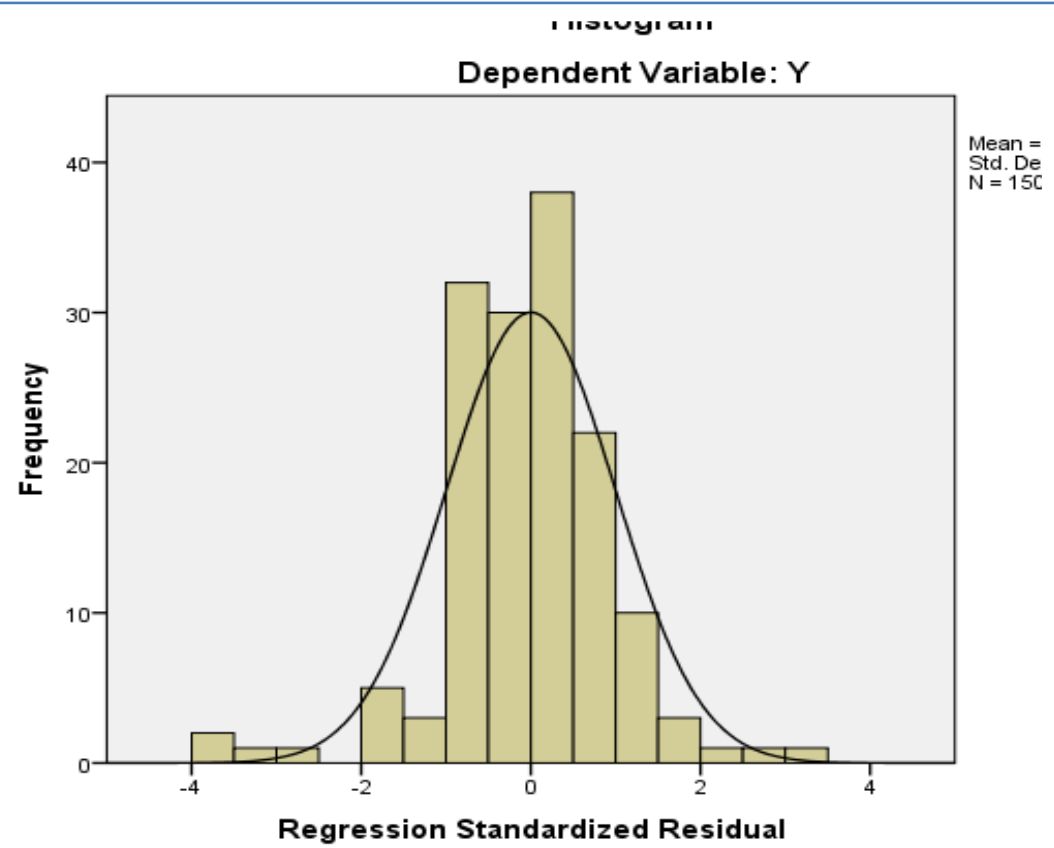

Gambar 2. Uji Normalitas pada Histogram

Hasil uji normalitas dalam gambar 2 menunjukkan bahwa data memiliki distribusi Normal, yang merupakan syarat untuk dapat dilakukan uji regresi. Karena berbentuk lonceng.

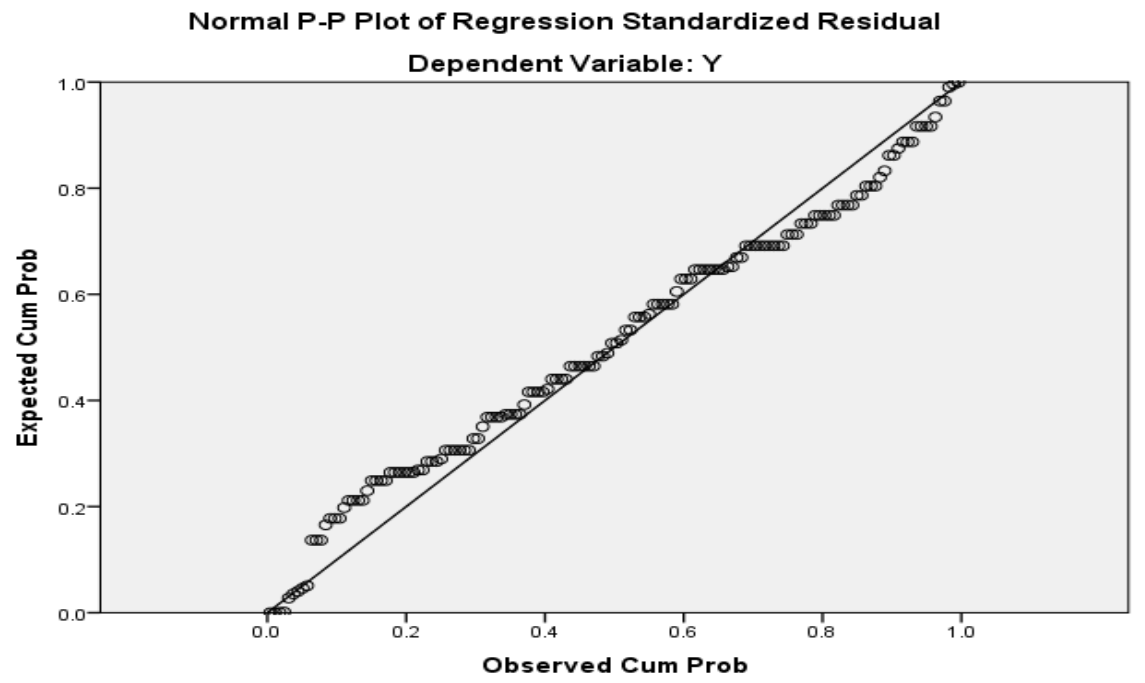

Gambar 3. Uji Normalitas Pada Normal P-Plot

Dengan cara uji analisis grafik normal p-plot (SPSS 19). Keberadaan titik-titik berada di sekitar garis menunjukkan bahwa distribusi normal. 


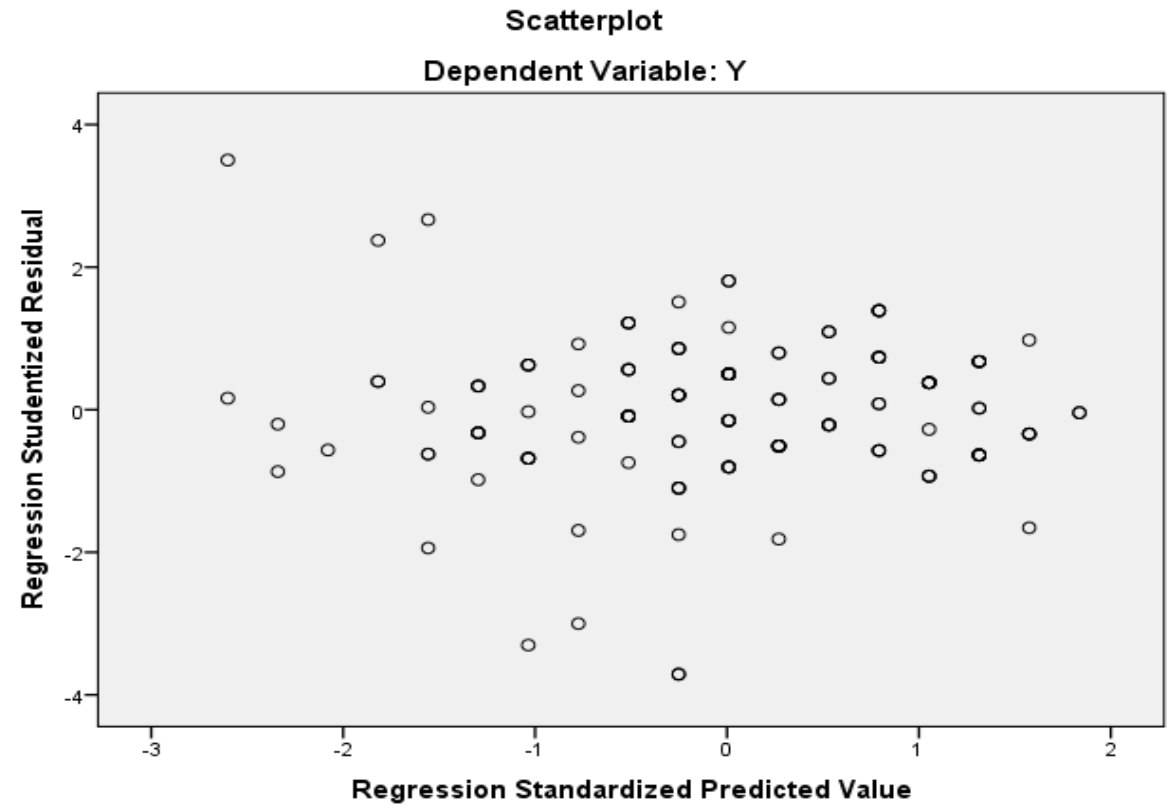

Gambar 4. Uji normalitas Pada scatterplot

Dengan cara uji analisis grafik normal Scatterplot (SPSS 19). Keberadaan titik-titik menyebar bahwa distribusi normal.

\section{HASIL UJI PENGARUH}

\section{Hasil Regresi Sederhana}

Digunakan untuk meramalkan Variabel dependen (Y) berdasarkan Variabel independen $(\mathrm{X})$ dalam suatu persamaan linear berikut:

\section{Coefficients $^{\mathbf{a}}$}

Tabel 7. Hasil Uji Regresi Sederhana

\begin{tabular}{|c|c|c|c|c|c|}
\hline \multirow[b]{2}{*}{ Model } & \multicolumn{2}{|c|}{ Unstandardized Coefficients } & \multirow{2}{*}{\begin{tabular}{|l} 
Standardized \\
Coefficients \\
Beta
\end{tabular}} & \multirow[b]{2}{*}{$\mathrm{T}$} & \multirow[b]{2}{*}{ Sig. } \\
\hline & B & Std. Error & & & \\
\hline (Constant) & .926 & .572 & & 1.619 & .108 \\
\hline $\mathrm{X}$ & .547 & .033 & .807 & 16.64 & .000 \\
\hline
\end{tabular}

a. Dependent Variable: Y

Sumber : Hasil Pengolahan SPSS 19

Adapun bentuk persamaan dari hasil perhitungan di atas adalah:

$\mathrm{Y}=\mathbf{0 . 9 2 6}+\mathbf{0 . 5 4 7 X}$

a. Nilai Konstanta (a) $=0,926$

Nilai konstanta positif menunjukkan pengaruh positif variabel $\mathrm{X}$, bila variabel $\mathrm{X}$ naik atau berpengaruh dalam satu satuan, artinya variabel Recall Audience (Y) akan naik atau terpenuhi.

b. Penayangan Film Animasi 3D Trailer $(\mathrm{X})=0,547$ 
Variabel Outlook Express (X) memiliki nilai koefisien regresi sebesar 0,547, ini berarti jika variabel independen lain nilainya tetap atau tidak berubah, maka setiap kenaikan 1 poin atau $1 \%$ yaitu 0,547 (54\%). artinya Penayangan Film Animasi 3D Trailer (X) memiliki sifat positif terhadap Recall Audience (Y).

\section{Hasil Uji R dan R Square}

Tabel 8. Hasil Uji R dan R Square

Model Summary ${ }^{b}$

\begin{tabular}{|c|c|c|c|c|c|}
\hline Model & $\mathrm{R}$ & R Square & $\begin{array}{l}\text { Adjusted R } \\
\text { Square }\end{array}$ & $\begin{array}{l}\text { Std. Error of the } \\
\text { Estimate }\end{array}$ & Durbin-Watson \\
\hline 1 & $.807^{\mathrm{a}}$ & .652 & .650 & 1.53760 & 1.234 \\
\hline
\end{tabular}

a. Predictors: (Constant), $\mathrm{X}$

b. Dependent Variable: Y

Sumber: hasil pengolahan SPSS 19

Berdasarkan tabel 8 dapat disimpulkan bahwa R Square = 0,652 artinya Penayangan Film Animasi 3D Trailer berpengaruh sebesar 65,20 \% Recall Audience, sedangkan 35,80 \% dipengaruhi variabel lain yang tidak diteliti. $\mathrm{R}=0,807$ korelasi antara variabel $\mathrm{X}$ dengan $\mathrm{Y}$ adalah $80,70 \%$.

\section{Hasil Uji t}

Digunakan untuk mengetahui pengaruh variabel independen $X$ (bebas) terhadap variabel dependen Y (terikat). Hipotesis dalam pengujian ini, sebagai berikut:

Ho $=$ Variabel $\mathrm{X}$ tidak berpengaruh terhadap variabel $\mathrm{Y}$.

H1 = Variabel X berpangaruh terhadap variabel $\mathrm{Y}$.

Kaidah pengambilan keputusan dalam pengujian ini adalah:

a. Jika t hitung $>\mathrm{t}$ tabel dan nilai Signifikan $<0,05$, maka H0 ditolak H1 diterima, jadi variabel independen $(\mathrm{X})$ berpengaruh terhadap variabel dependen $(\mathrm{Y})$.

b. Jika $\mathrm{t}$ hitung $<\mathrm{t}$ tabel dan signifikan $>0,05$ maka H0 diterima dan H1 ditolak, artinya variabel independen $(\mathrm{X})$ tidak berpengaruh terhadap variabel dependen $(\mathrm{Y})$.

Tabel 4.9. Hasil Uji $t$

\section{Coefficients $^{\mathrm{a}}$}




\begin{tabular}{|c|c|c|c|c|c|c|}
\hline \multirow{2}{*}{\multicolumn{2}{|c|}{ Model }} & \multicolumn{2}{|c|}{$\begin{array}{l}\text { Unstandardized } \\
\text { Coefficients }\end{array}$} & \multirow{2}{*}{$\begin{array}{l}\text { Standardized } \\
\text { Coefficients } \\
\text { Beta }\end{array}$} & \multirow[b]{2}{*}{$\mathrm{T}$} & \multirow[b]{2}{*}{ Sig. } \\
\hline & & B & Std. Error & & & \\
\hline \multirow[t]{2}{*}{1} & $($ Constant $)$ & .926 & .572 & & 1.619 & .108 \\
\hline & $X$ & .547 & .033 & .807 & 16.648 & .000 \\
\hline
\end{tabular}

a. Dependent Variable: Y

Sumber : Hasil Pengolahan SPSS 19

Pengaruh Penayangan Film Animasi 3D Trailer (X) Terhadap Recall Audience (Y) t hitung $(16,648)>t$ tabel $(1.9762)$. Nilai Signifikan $=000<0.05$, maka H0 ditolak H1 diterima. Jadi variabel independen $(\mathrm{X})$ berpengaruh terhadap variabel dependen $(\mathrm{Y})$.

\section{PEMBAHASAN}

\section{A. Penayangan film animasi 3D trailer menarik pengunjung pada bioskop blitz harbour mall bay Batam.}

Skor tertinggi adalah "Tampilan Penayangan Film Animasi 3D Trailer Sangat menarik untuk di tonton." dengan jumlah skor sebesar 552 atau dengan kontribusi sebesar 14.72\%, sedangkan skor terendah yaitu "Penayangan Film Animasi 3D Trailer memiliki animasi yang bagus dan Suara yang Jernih seperti nyata" dengan jumlah skor 486 atau dengan kontribusi sebesar $12.96 \%$. Dari data tersebut dapat diambil kesimpulan bahwa pernyataan "Tampilan Penayangan Film Animasi 3D Trailer Sangat menarik untuk di tonton" dinilai menarik pengunjung. juga dapat dilihat rata-rata skor total yaitu 518.6 berada pada rentang skala 513633 yang telah ditentukan sebelumnya (tabel 3.5 Rentang Skala). Dengan demikian hipotesis 1 diterima, hal ini Penayangan film animasi 3D trailer menarik pengunjung.

\section{B. Recall audience meningkat pada bioskop Blitz Harbour bay Batam.}

Skor tertinggi adalah "Film yang mempunyai Kesan Humor memiliki daya tarik Penonton agar ingin menonton." dengan jumlah skor sebesar 529 atau dengan kontribusi sebesar $23.51 \%$, sedangkan skor terendah yaitu "Film animasi 3D memiliki daya tarik Rasional yang bersifat memberikan pesan moral kepada Penonton" dengan jumlah skor 452 atau dengan kontribusi sebesar $20.08 \%$. Dari data tersebut dapat diambil kesimpulan bahwa pernyataan "Film animasi 3D memiliki daya tarik Rasional yang bersifat memberikan pesan moral kepada Penonton" dinilai recall audience meningkat. juga dapat dilihat rata-rata skor total yaitu 4371 berada pada rentang skala 392 - 512 yang telah ditentukan sebelumnya 
(tabel 3.5 Rentang Skala). Dengan demikian hipotesis 2 diterima, hal ini Penayangan film animasi 3D trailer cukup menarik pengunjung.

\section{Penayangan Film animasi 3D trailer berpengaruh signifikan terhadap Recall audience di bioskop Harbour Bay Mall Batam.}

Berdasarkan pengolahan data didapatkan variabel Penayangan Film Animasi 3D Trailer (X) Terhadap Recall Audience $(\mathrm{Y}) \mathrm{t}$ hitung $(16,648)>\mathrm{t}$ tabel $(1.9762)$, maka H0 ditolak dan H1 diterima. Dengan demikian variabel independen $(\mathrm{X})$ berpengaruh terhadap variabel dependen (Y). Dari kriteria tersebut maka hipotesis 3 diterima, yang berarti Penayangan Film Animasi 3D Trailer berpengaruh terhadap signifikan terhadap Recall audience di bioskop Harbour Bay Mall Batam.

\section{V.SIMPULAN}

Dari uraian hasil penelitian dan pembahasan penelitian sebagaimana yang peneliti lakukan, maka dapat ditarik beberapa kesimpulan yaitu sebagai berikut:

1. Berdasarkan Penelitian, Penayangan film animasi 3D trailer menarik pengunjung pada bioskop blitz harbour mall bay Batam.

2. Berdasarkan Penelitian, Recall audience meningkat pada bioskop Blitz Harbour bay Batam.

3. Berdasarkan Penelitian, Penayangan Film animasi 3D trailer berpengaruh signifikan terhadap Recall audience di bioskop Harbour Bay Mall Batam.

\section{DAFTAR PUSTAKA}

Aditya (2009) . Trik Dahsyat Menjadi Animator 3D Andal. Penerbit Andi. Yogyakarta.

Furniss, M. 2008. The Animation Bible: A Guide to Everything - From Flipbooks to Flash. London: Laurence King Publishing Ltd.

Keller, K.L. (2003) Strategic Brand Management. 2nd edition. Upper Saddle River, NJ: Prentice Hall.

Lee, W.W. \& Owens, D. L. (2004). Multimedia-based instruction design: computer-basedtraining, web-based training, distance broadcast training, performance-based solution. New York: Pfeiffer.

Mayer, R. E. \& Moreno, R. (2002). Animation as an aid multimedia learning. educational psychology review, Vol. 14, No.1, March 2002. Diakses dari http://ydraw.com/wpcontent/uploads/2012/04/Stop-Motion-Aids-Multimedia-Learning.pdf pada tanggal 20 November 2014.

Keller, K.L. (2003) Strategic Brand Management. 2nd edition. Upper Saddle River, NJ: Prentice Hall. 
Lee, W.W. \& Owens, D. L. (2004). Multimedia-based instruction design: computer-basedtraining, web-based training, distance broadcast training, performance-based solution. New York: Pfeiffer.

Mayer, R. E. \& Moreno, R. (2002). Animation as an aid multimedia learning. educational psychology review, Vol. 14, No.1, March 2002. Diakses dari http://ydraw.com/wpcontent/uploads/2012/04/Stop-Motion-Aids-Multimedia-Learning.pdf pada tanggal 20 November 2014.

Suyanto.M, 2007. Marketing Strategi Top Brand Indonesia. Yogyakarta : Penerbit Andi.

Suyanto, M. 2005. Multimedia Alat untuk Meningkatkan Keunggulan Bersaing. Yogyakarta. Andi Offset.

Prasetyo, Bambang dan Lina Miftahul Jannah. (2012). Metode Penelitian Kuantitatif : Teori dan Aplikasi. Rajawali Pers. Jakarta.

Priyatno, Duwi. (2010). Paham Analisa Statistik Data dengan SPSS. MediaKom. Yogyakarta.

Riduwan. (2010). Metode dan Teknik Menyusun Tesis. Penerbit ALFABETA. Bandung.

Sugiyono. (2012). Metode Penelitian Kualitatif, Kuantitatif dan R\&D. Cetakan ke - 16. Penerbit ALFABETA. Bandung.

Sujarweni dan Endrayanto. (2012). Statistika untuk Penelitian. Graha Ilmu. Yogyakarta.

Santoso, Singgih. (2000). Buku Latihan SPSS Statistik Parametik. PT. Elek Media Komputindo. Jakarta.

Wibowo, Agung Edy. (2012). Aplikasi Praktis SPSS dalam Penelitian. Penerbit Gava Media. Yogyakarta.

Wells, William, et al. 2007. Advertising Principles and Effective IMC Practice. South Asia Pte Ltd, Copyright by Pearson Education.

Wyatt, A. 2010. The Complete Digital Animation Course: The Principles, Practice and Techniques of Successful Digital Animation. London: Thames \& Hudson Ltd.

\section{Jurnal}

1. Abdullah, Fadli dan Md Sidin Ahmad Ishak. 2010. Pembangunan Sektor Animasi di Malaysia: Pendidikan dan Latihan Animasi di Institusi Pengajian Tinggi Awam. Malaysian Journal of Media Studies Volume 12. Pp. 69-82. Vol. 12, No. 2, 2010

2. Berta Sihite Dkk. 2013. "Pembuatan Aplikasi 3D Viewer Mobile dengan Menggunakan

Teknologi Virtual Reality (Studi Kasus: Perobekan Bendera Belanda di Hotel Majapahit)”. JURNAL TEKNIK POMITS Vol. 2, No. 2, (2013) ISSN: 2337-3539 (23019271 Print)

3. Diana Sari. 2012 "perencanaan kebutuhan pengguna pada produksi film animasi Tiga dimensi untuk pengembangan groupware" TEK-KOM, Vol. 14, No. 2, Desember 2012 (133-150). ISSN: 1410-3346

4. Ikhsan Natigor dan Endang Sulistya Rini. 2011. "Analisis Pengaruh Penayangan Movie Trailer Dan Store Environtment Terhadap Recall Audience Pada Bioskop 21 Medan" Jurnal Ekonom, Vol 14, No 3, Juli 2011 
5. Alyasa, Fariz Hadi dan Nunik Kusnilawati. 2012. Analisis Pengaruh Ekuitas Merek (Brand Equity) Terhadap Loyalitas Konsumen Pada Produk Sepeda Motor Kawasaki Ninja. Jurnal Mahasiswa Q-MAN, 1(2), h:1 -14.

6. Chahal, Hardeep dan Madhu Bala. 2012. Significant components of service brand equity in healthcare sector. International Journal of Health Care Quality Assurance, 25(4), Pp:343-362.

7. Munas, Bambang dan Faela Sufa. 2012. Analisis Pengaruh Daya Tarik Iklan, Kualitas Pesan Iklan, Frekuensi Penayangan Iklan Terhadap Efektivitas Iklan Televisi Mie Sedap (Survei Pemirsa Iklan Mie Sedap Pada Mahasiswa Kost di sekitar Kampus Undip, Tembalang). Diponegore Journal Of Management, 1(1), h: 226-233.

8. Pracista, Ni Muni dan Gede Bayu Rahanatha. 2014. Pengaruh Kredibilitas Celebrity Endorser, Daya Tarik Iklan Dan Kepuasan Pelanggan Terhadap Ekuitas Merek (Brand Equity) Dari Produk Sampo L'oreal Pada Konsumen Wanita (Studi Kasus Di Kota Denpasar). Jurnal Manajemen Universitas Udayana. Pp : 1873 - 1874. Vol 3, No 7 (2014)

9. Taylor, Steven A. Garry L. Hunter dan Deborah L. Lindberg. 2007. Understanding (customer-based) brand equity in financial services. Journal of Services Marketing, 21(4), pp: 241-252.

10.Sasetyo, Septa Adi, Hussein nawawi dan Roy Rondonuwu. 2012. Pengaruh Daya Tarik Iklan Terhadap Pembentukan Citra Merek Pepsoden. Ejurnal Mahasiswa Universitas Padjadjaran, 1(1), h: 1-19.

11.Zboja, James J. dan Clay M F. Voorhess. 2006. The Impact of Brand Trust and Satisfaction on Retailer Repurchase intentions. Journal of Services Marketing, 20(5), pp: 381-390. 